\title{
Noma disease (cancrum oris, orofacial gangrene) in an acute myeloid leukemia patient: a case report
}

\author{
Jiho Park', Sanghun Kim', Seung-Woo Shin ${ }^{1}$, Chuhl Joo Lyu² and Dongwook Kim ${ }^{1 *}$ (1)
}

\begin{abstract}
Background: Noma is a rare disease that occurs mainly in malnourished patients in developing countries. Noma starts as facial swelling and gingival necrosis that eventually necrotizes underlying tissues including the jaw bone, leaving severe disfigurement. It is reported extremely rarely in patients with severe immunosuppression or blood dyscrasia.
\end{abstract}

Case presentation: The gingivitis that occurred in a 12-year-old Asian female patient with acute myeloid leukemia was getting increasingly worse. Although the proper treatment was done, the patient's condition did not improve, and eventually, a large full-thickness defect was left in the maxillofacial part.

Conclusions: Early diagnosis and management is the only way to prevent the progression, which leads to facial disfigurement. We present a case of noma in a pediatric acute myeloid leukemia patient, in which oral function was restored through surgical intervention.

Keywords: Noma, Cancrum oris, Orofacial gangrene, Acute myeloid leukemia, Facial disfigurement

\section{Introduction}

Noma (orofacial gangrene, cancrum oris) is a cryptogenic disease that leads to severe orofacial destruction [1]. Starting as gingivitis, noma develops into gingival necrosis that spreads to the underlying tissues, eventually involving the jawbone. The corresponding facial region develops swelling and subsequently necrotizes, leading to the destruction of soft and hard facial tissues to leave severe disfigurement.

Noma is known to occur mainly in patients with the following conditions: extreme poverty, severe malnutrition, unsafe drinking water, poor sanitation, poor oral health practices, high infant mortality, limited access to high-quality health care, and intrauterine growth

*Correspondence: DWKIMOMFS@yuhs.ac

${ }^{1}$ Department of Oral \& Maxillofacial Surgery, College of Dentistry, Yonsei University, Seoul, Korea

Full list of author information is available at the end of the article retardation; usually in developing countries, but other cases are also reported extremely rarely, including those with human deficiency virus (HIV) infection, cyclic neutropenia, leukemia, Down's syndrome, Burkett's disease, and herpetic stomatitis [2-4].

In this study, we report 12-year-old female who suffered leukemia with a complication of noma disease on her lower face.

\section{Case report}

A 12-year-old Asian female patient was referred from the pediatric hematology-oncology service, department of pediatrics, for the evaluation and management of swollen gingiva and chin (Fig. 1). The patient had a history of patent ductus arteriosus (PDA) closure at age 6 . She underwent four cycles of induction chemotherapy for acute myeloid leukemia (AML), which had been diagnosed a year previously. She was admitted for the management of neutropenic fever over $39{ }^{\circ} \mathrm{C}$. She was on antibiotics original author(s) and the source, provide a link to the Creative Commons licence, and indicate if changes were made. The images or other third party material in this article are included in the article's Creative Commons licence, unless indicated otherwise in a credit line to the material. If material is not included in the article's Creative Commons licence and your intended use is not permitted by statutory regulation or exceeds the permitted use, you will need to obtain permission directly from the copyright holder. To view a copy of this licence, visit http://creativecommons.org/licenses/by/4.0/. The Creative Commons Public Domain Dedication waiver (http://creativeco mmons.org/publicdomain/zero/1.0/) applies to the data made available in this article, unless otherwise stated in a credit line to the data. 

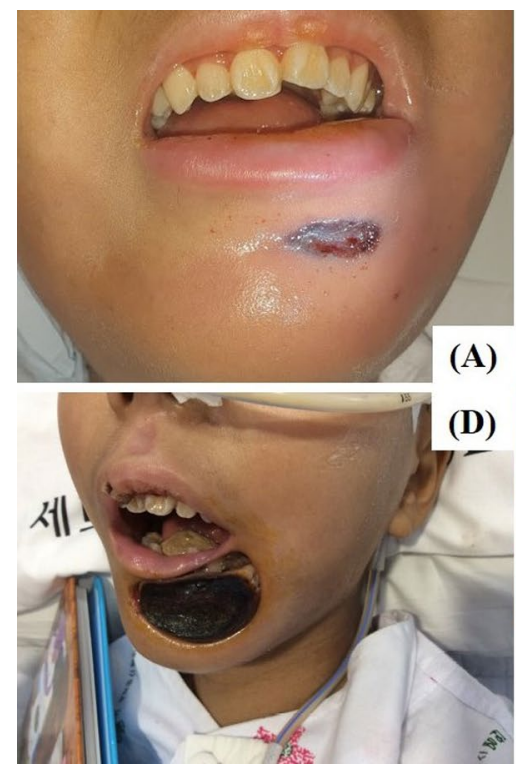

(D)

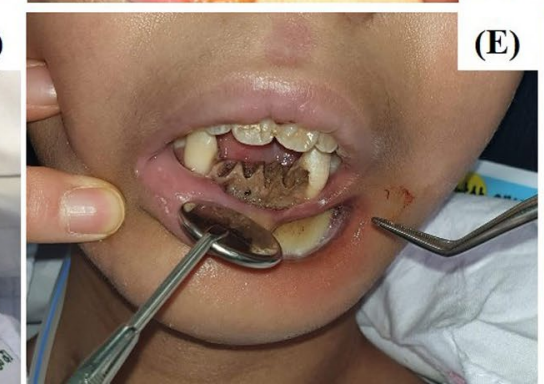

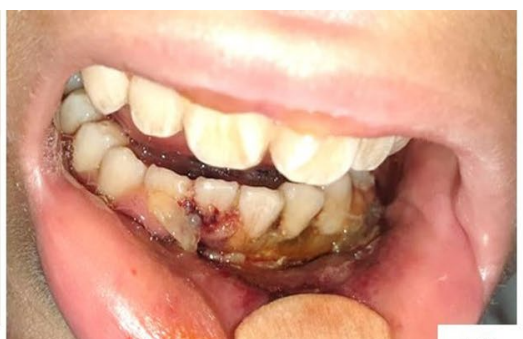

(B)

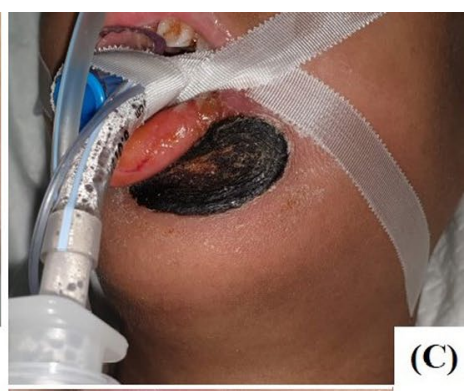

(E)

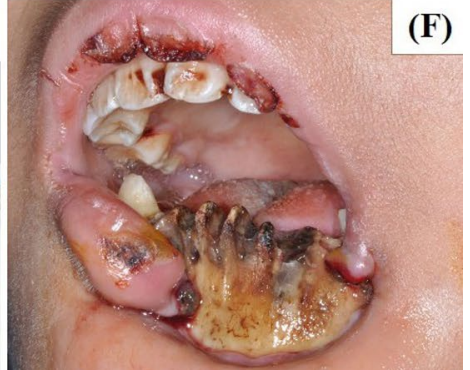

Fig. 1 Initial presentation and progression of lesion. A and $\mathbf{B}$ Ecchymosis of chin and necrotizing gingivitis is noted. C 1 week, D 3 weeks, E 5 weeks, and $\mathbf{F} 7$ weeks after the initial presentation. The necrotic portion of mandible and the alveolar bone spontaneously fell off afterwards

(linezolid, meropenem, sulfamethoxazole, metronidazole, teicoplanin, cefpiramide, amikacin), antifungals (fluconazole, nystatin, amphotericin B, voriconazole, caspofungin), and an antiviral (acyclovir) for her febrile condition, under the impression of neutropenic fever and vancomycin-resistance enterococci (VRE) sepsis. The results of complete blood count with differential were as follows: white blood cell (WBC) counts $40 / \mu \mathrm{L}$, platelet counts $8000 / \mu \mathrm{L}$, absolute neutrophil count $0 / \mu \mathrm{L}$.

As the patient was already on every possible antibiotic, antifungal, and antiviral, close observation and oral hygiene maintenance was the only possible management. Surgical intervention was contraindicated due to her systemic condition, especially considering her hematologic status. Six days after the initial presentation, the patient developed cardiac arrest under the background of uncontrolled fever. Return of spontaneous circulation was achieved after resuscitation, and her general condition improved as days went by. The oral and facial lesion progressed to full-thickness gangrene and underlying alveolar bone separated from the surrounding mandible (Fig. 1). Teeth on the segment spontaneously fell out (Fig. 1). The necrotic alveolar bone segment also spontaneously fell out.

After the patient had become afebrile and able to return to regular activities, not only the disfigurement but the incompetency of the lips and resultant drooling posed severe obstacles in her daily life since oral intake was disabled. Considering the pancytopenic condition of the patient, surgical repair was done as simply as possible, by local flap, to achieve continuity of the orbicularis oris muscle and competency of the lip, thus enabling oral intake afterwards (Fig. 2).

\section{Discussion and conclusions}

Noma was first described in 1595 by Carolus Battus, and since then many cases have been reported [5]. Following advances in medical science, novel epidemiological investigations and surgeries on noma were conducted in the 1800s [6]. In 1926, Smith et al. presented the first case of cancrum oris in leukemia patients after a postmortem examination of a patient who died of hospitalization due to severe pain in the left facial area. In 2010, Krishnamurthy et al. reported a case of cancrum oris in a patient with chemotherapy for acute myeloid leukemia [7, 8].

Annually, the incidence and prevalence of noma is reported as 140,000 and 770,000 cases, respectively. The epidemiology of noma has not changed much over the years, except that there has been a reduction in the mortality rate from $90 \%$ to about $8-10 \%$, mainly due to modern antibiotics $[9,10]$. Early diagnosis and management are the only way to prevent progression of the disease and resulting severe facial disfigurement.

Based on World Health Organization guidelines for noma in 2016, the optimal standard of care is to start antibiotic treatment as early as possible [4]. Although the patient in this report was already undergoing treatment with a wide range of antibiotic, antifungal, and antiviral drugs for the management of neutropenic 

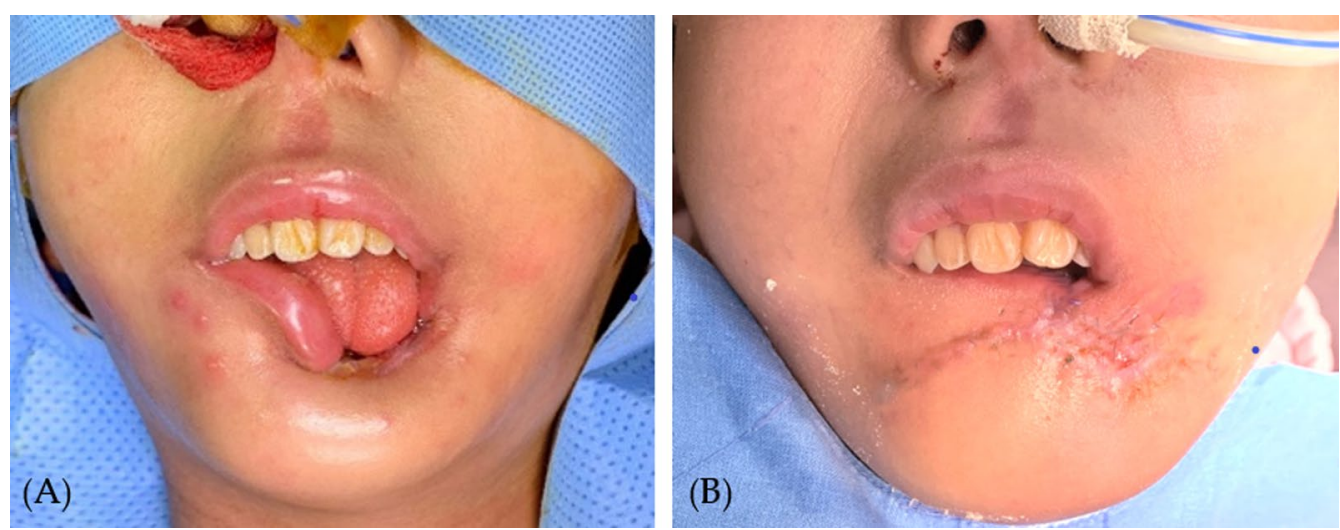

Fig. 2 Preoperative and postoperative appearance

fever, the lesion progressed and resulted in full-thickness defects including the underlying mandible.

Defects in the lower face can occur for various reasons, such as trauma and malignant tumors, and if accompanied by lip incompetency and drooling, greatly affect daily life. Repairing such defects will help enable oral intake and enhance appearance as well. Though there are various methods, including local and free flaps, to repair or reconstruct the lip and lower facial defects, a minimally invasive approach should be considered in such a pancytopenic patient. Flipping the buccal skin flap to repair the oral side and recovering the continuity of the orbicularis oris muscle was the key step of the repair.

With advances in medicine and living standards, noma has come to be regarded as a region-specific disease. It was thus initially difficult to achieve proper diagnosis of its occurrence in an acute myeloid leukemia patient as reported here. We report this case of noma in a child with leukemia to emphasize that this rare disease is not confined to the malnourished, but may also occur in patients with deliberately suppressed immune systems [11].

\section{Abbreviations}

AML: Acute myeloid leukemia; VRE: Vancomycin-resistance enterococci; WBC: White blood cell.

\section{Acknowledgements}

Not applicable.

\section{Authors' contributions}

$J \mathrm{H}, \mathrm{CJ}$, and DW cared for the patient. JH, SW, and DW drafted the case report. All authors read and approved the final manuscript.

\section{Funding}

This study was supported by a new faculty research seed money grant of Yonsei University College of Dentistry for 2020 (2020-32-0014.)

\section{Availability of data and materials} Not applicable.

\section{Declarations}

Ethics approval and consent to participate

This study was conducted in accordance with the fundamental principles of the latest revised Declaration of Helsinki. This study was obtained for exemption from IRB of number 2-2020-0109

\section{Consent for publication}

Written informed consent was obtained from the patient's legal guardian for publication of this case report and any accompanying images. A copy of the written consent is available for review by the Editor-in-Chief of this journal.

\section{Competing interests}

The authors declare that they have no competing interests.

\section{Author details}

'Department of Oral \& Maxillofacial Surgery, College of Dentistry, Yonsei University, Seoul, Korea. ${ }^{2}$ Department of Pediatrics, College of Medicine, Yonsei University, Seoul, Korea.

Received: 8 March 2021 Accepted: 8 February 2022

Published online: 08 March 2022

\section{References}

1. Baratti-Mayer D, Pittet B, Montandon D, Bolivar I, Bornand J-E, Hugonnet S, Jaquinet A, Schrenzel J, Pittet D. Noma: an "infectious" disease of unknown aetiology. Lancet Infect Dis. 2003;3:419-31. https://doi.org/10. 1016/S1473-3099(03)00670-4

2. Weinstein RA, Choukas NC, Wood WS. Cancrum oris-like lesion associated with acute myelogenous leukemia. Oral Surg Oral Med Oral Pathol. 1974;38:10-4. https://doi.org/10.1016/0030-4220(74)90305-3.

3. Hatcher J, Williamson L. Noma in a patient with HIV. Lancet Infect Dis. 2017;17:672. https://doi.org/10.1016/S1473-3099(17)30263-3.

4. World Health Organisation (WHO). Noma is a severe disease. It is treatable if detected and managed early. Geneva: WHO; 2016. p. 1-24.

5. Marck K, Bruijn H. Surgical treatment of noma. Oral Dis. 2008:5:167-71. https://doi.org/10.1111/j.1601-0825.1999.tb00084.x.

6. Marck KW. A history of noma, the "Face of Poverty." Plast Reconstr Surg. 2003;111:1702-7. https://doi.org/10.1097/01.PRS.0000055445.84307.3C.

7. Smith EC. Cancrum oris in a case of leukæmia. Trans R Soc Trop Med Hyg. 1926;19:394-6. https://doi.org/10.1016/S0035-9203(26)90506-3.

8. Krishnamurthy A, Sundersingh S, Srinivas S, Vaidhyanathan A, Lnu K. Cancrum oris-associated with acute myeloid leukemia: a forgotten disease. Int J Head Neck Surg. 2010;1:167-9. https://doi.org/10.5005/jp-journ als-10001-1032. 
9. Auluck A, Pai KM. Noma: life cycle of a devastating sore-case report and literature review. J Can Dent Assoc. 2005;71:757.

10. Oji C. Cancrum oris: its incidence and treatment in Enugu, Nigeria. Br J Oral Maxillofac Surg. 2002;40:406-9. https://doi.org/10.1016/S02664356(02)00192-4.

\section{Publisher's Note}

Springer Nature remains neutral with regard to jurisdictional claims in published maps and institutional affiliations.

- fast, convenient online submission

- thorough peer review by experienced researchers in your field

- rapid publication on acceptance

- support for research data, including large and complex data types

- gold Open Access which fosters wider collaboration and increased citations

- maximum visibility for your research: over $100 \mathrm{M}$ website views per year

At BMC, research is always in progress.

Learn more biomedcentral.com/submissions 